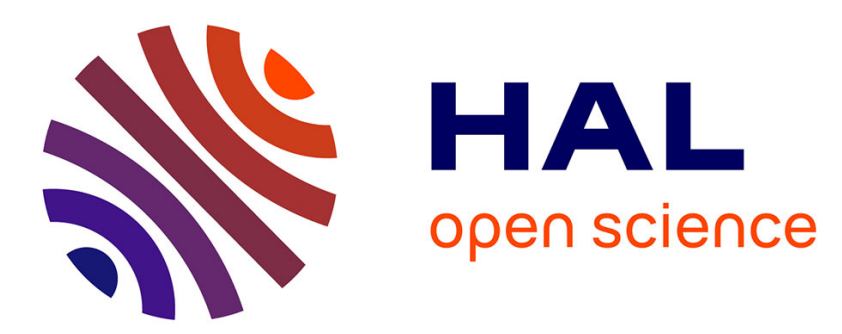

\title{
Application of Kelvin probe Force Microscopy (KFM) to evidence localized corrosion of over-aged aeronautical 2024 aluminum alloy
}

\author{
Nicoleta Radutoiu, Joël Alexis, Loïc Lacroix, Marioara Abrudeanu, \\ Jacques-Alain Petit
}

\section{To cite this version:}

Nicoleta Radutoiu, Joël Alexis, Loïc Lacroix, Marioara Abrudeanu, Jacques-Alain Petit. Application of Kelvin probe Force Microscopy (KFM) to evidence localized corrosion of over-aged aeronautical 2024 aluminum alloy. Key Engineering Materials, 2013, vol. 550, pp. 127-134. 10.4028/www.scientific.net/KEM.550.127 . hal-00854415

\section{HAL Id: hal-00854415 \\ https://hal.science/hal-00854415}

Submitted on 27 Aug 2013

HAL is a multi-disciplinary open access archive for the deposit and dissemination of scientific research documents, whether they are published or not. The documents may come from teaching and research institutions in France or abroad, or from public or private research centers.
L'archive ouverte pluridisciplinaire HAL, est destinée au dépôt et à la diffusion de documents scientifiques de niveau recherche, publiés ou non, émanant des établissements d'enseignement et de recherche français ou étrangers, des laboratoires publics ou privés. 


\section{Open Archive Toulouse Archive Ouverte (OATAO)}

OATAO is an open access repository that collects the work of Toulouse researchers and makes it freely available over the web where possible.

This is an author-deposited version published in: http://oatao.univ-toulouse.fr/ Eprints ID: 4091

To link to this article: DOI:10.4028/www.scientific.net/KEM.550.127 http://www.scientific.net/KEM.550.127

\section{To cite this version:}

Radutoiu, Nicoleta and Alexis, Joël and Lacroix, Loïc and Abrudeanu, Marioara and Petit, Jacques-Alain Application of Kelvin probe Force Microscopy (KFM) to evidence localized corrosion of over-aged aeronautical 2024 aluminum alloy. (2013) International Journal Key Engineering Materials, vol. 550. pp. 127-134. ISSN 1013-9826 


\title{
Application of Kelvin probe Force Microscopy (KFM) to evidence localized corrosion of over-aged aeronautical 2024 aluminum alloy
}

\author{
Nicoleta Radutoiu ${ }^{1,2}$, Joël Alexis ${ }^{1}$, Loïc Lacroix ${ }^{1, a}$, Marioara Abrudeanu², \\ Jacques-Alain Petit ${ }^{1}$ \\ ${ }^{1}$ University of Toulouse, LGP-ENIT/INPT, 47 avenue d'Azereix, BP 1629, 65016 Tarbes, France \\ ${ }^{2}$ University of Pitesti, Str. Targul din Vale, nr.1, 110040 Pitesti, Arges, Roumanie
}

aloic.lacroix@enit.fr

Keywords: Heat treatment, AA2024 aluminum alloy, microstructure, corrosion, AFM.

\begin{abstract}
The 2xxx serie aluminum alloys are characterized by good mechanical performances and low density, however they are susceptible to different forms of localized corrosion: pitting corrosion, intergranular corrosion and stress corrosion cracking. The 2024-T351 aluminum alloy is used in the aircraft industry for numerous applications such as fuselage and door skin. Corrosion damage of the material is also very detrimental for the structural integrity of the aircraft. The presence of coarse intermetallic particles, with a heterogeneous size distribution was found to be responsible for the 2024 susceptibility to localized corrosion. These particles are generally the cause of initiation sites. Presence of micro-defects in the oxide film upon coarse intermetallic particles and the galvanic coupling with the matrix contribute to the development of pitting corrosion. The over-ageing treatment (T7) is supposed to stabilize the microstructure and the mechanical properties to improve the corrosion resistance. The 2024 alloy microstructure after the $\mathrm{T} 7$ heat treatment remains very complex. The 2024 alloy corrosion behavior was studied in the over-ageing state for three different temperatures $\left(150,175\right.$ and $\left.190{ }^{\circ} \mathrm{C}\right)$. During the corrosion tests in chloridecontaining environment, the behavior of coarse intermetallic particles was found to be different. Thus, the 2024 samples suffer a gradual attack upon $\mathrm{S}-\mathrm{Al}_{2} \mathrm{CuMg}$ particles and finally $\mathrm{Al}(\mathrm{Cu}, \mathrm{Mn}, \mathrm{Fe}, \mathrm{Si})$ particles. The corrosion damage was studied by Atomic Force Microscopy (AFM) and Kelvin probe Force Microscopy (KFM). This technique allows simultaneous topographical and electric potential mapping to be obtained. This latest potential was shown to be correlated to the corrosion potential of the 2024 alloy. This study focuses on the variation of the KFM potential of the coarse intermetallic particles and the matrix for the over-ageing conditions (T7). Observations using optical microscope and AFM were also performed to obtain the corrosion rate for each condition. The corrosion rate was correlated to the chemical composition variation of the particles obtained by scanning electron microscope observations and EDS analyses.
\end{abstract}

\section{Introduction}

The 2024 aluminum alloy is used in the aircraft industry for numerous applications like fuselage, door skins, dorsal fin, wing skin and stringers, due to its high strength-to-weight ratio, good damage tolerance and low cost [1].

In the AA2024 alloy a heterogeneous microstructure is developed by addition of copper and magnesium to improve the mechanical properties. After a heat treatment, the AA2024 alloy presents optimal mechanical properties for use in aircraft applications. Unfortunately, this alloy is extremely susceptible to localized corrosion in sodium chloride environments, such as: pitting corrosion, intergranular corrosion, stress corrosion cracking [2-10]. The intermetallic particles are responsible for the susceptibility to localized corrosion of the $2 \mathrm{xxx}$ series alloys. These intermetallic particles are considered to be the initiation sites for localized corrosion in the 2024 alloys as a consequence of the presence of defects in the oxide surrounding of intermetallic particles and the galvanic coupling between the matrix and intermetallic particles. 
The Atomic Force Microscopy (AFM) allowed obtaining the topography with high lateral resolution. In order to understand the corrosion behavior of the 2024 aluminum alloy techniques associated with atomic force microscopy were developed. The combination of atomic force microscopy (AFM) with Kelvin probe force microscopy (KFM) allows simultaneous topographical analysis and potential mapping. This combination has appeared to be a powerful technique to study the localized corrosion phenomena. The AFM/KFM technique has been used to characterize the polished surface before and after immersion into various electrolytes [11-13].

In this paper, AFM/KFM measurements were performed in order to study the evolution of the corrosion potential of coarse intermetallic particles. Thus, more than 100 intermetallic particles of the over-aged 2024 aluminum alloy, before and after immersion in chloride-containing sulfate solutions were studied. The variation of the chemical composition was followed by scanning electron microscope observations and EDX analyses. The corrosion rate was determinate by optical microscopy observations and AFM/KFM analyses.

\section{Experimental}

Material. Corrosion experiments were performed on the 2024 aluminum alloy after the over-ageing process. The chemical composition of AA2024 alloy was presented in our previous paper [14]. All specimens were cut in order to test the longitudinal (L) direction of the material. The samples with size of $1 \mathrm{~cm}^{3}$ were treated at $495 \pm 5^{\circ} \mathrm{C}$ in an air circulating furnace for 1 hour, quenched into cold water and immediately aged at three different temperatures: $150{ }^{\circ} \mathrm{C}, 175^{\circ} \mathrm{C}$ and $190{ }^{\circ} \mathrm{C}$. The treatment duration for each temperature $\left(36\right.$ days at $150^{\circ} \mathrm{C}, 50 \mathrm{hrs}$ at $175^{\circ} \mathrm{C}$ and $24 \mathrm{hrs}$ at $190^{\circ} \mathrm{C}$ ) was defined after the macrohardness stabilized [14].

All specimens were polished prior to corrosion test. The samples $(10 \times 10 \times 2 \mathrm{~mm})$ were mechanical polished with up to 4000 grit silicon carbide papers, before final polishing with diamond pastes. Final polishing was performed with $3 \mu \mathrm{m}$ diamond paste down to $1 / 4 \mu \mathrm{m}$ paste using ethanol as lubricant.

Corrosion test. Polished specimens were immersed at open circuit potential in a $0.1 \mathrm{M}$ $\mathrm{Na}_{2} \mathrm{SO}_{4}$ solution with $0,001 \mathrm{M} \mathrm{NaCl}$ at room temperature. The electrolyte for all tests, were prepared with Rectapur chemicals dissolved in deionized water. The temperature of the electrolyte was controlled and maintained at $22^{\circ} \mathrm{C}$ by using thermostat. The samples surface was always prepared just before corrosion exposure to prevent the appearance of the oxide layer and to provide reproducible results. Before any drying, the corroded samples were ultrasonically cleaned in water to dissolve the corrosion products. Finally, the samples were ultrasonically cleaned in ethanol and air-dried.

The chloride-containing sulfate environment was chosen to protect the matrix against pitting corrosion and to locate the corrosion phenomena on cooper rich particles $\left(\mathrm{Al}_{2} \mathrm{CuMg}\right)$.

AFM/KFM observations. The AFM/KFM measurements were performed on a Digital Instrument Nanoscope III Multimode. The KFM potential with respect to the aluminum matrix was investigate. All measurements were carried out in air at ambient temperature with a lift height of 50 $\mathrm{nm}$ and a lateral resolution better than $100 \mathrm{~nm}$. The potential of coarse intermetallic particles were defined by the difference of the KFM potential between the intermetallic particle ant the matrix remote from the particle.

The samples were ultrasonically cleaned in ethanol and air dried to limit any effect of adsorbed species on Volta potential value. On the topographic and potential images, brightness is proportional to height and, potential, respectively.

Microscopic observations. Analyses and observations of the microstructure with an optical microscope and a scanning electron microscope showed the presence of coarse intermetallic particles such as $\mathrm{Al}_{2} \mathrm{CuMg}$ and $\mathrm{Al}(\mathrm{Cu}, \mathrm{Mn}, \mathrm{Fe}, \mathrm{Si})$. 
After corrosion exposure, specimens were firstly examined by optical microscopy, in order to obtain information concerning the distribution and number of intermetallic particles corroded. Scanning electron microscopy (SEM) observations were performed in order to study the behavior of coarse intermetallic particles. Finally, energy dispersed spectrometry (EDS) analysis was performed to assess the chemical composition of coarse intermetallic particles, before and after corrosion experiments.

\section{Results and discussions}

AFM/KFM measurements. As it is known, two types of coarse intermetallic particles can be found in the 2024 aluminum alloy: $\mathrm{Al}_{2} \mathrm{CuMg}$ particles and $\mathrm{Al}(\mathrm{Cu}, \mathrm{Mg}, \mathrm{Fe}, \mathrm{Si})$ particles. In this study, the corrosion behavior was investigated by comparing the rate of corroded particles in the peak-aged an over-aged state for the three aged temperatures $\left(150,175\right.$ and $\left.190^{\circ} \mathrm{C}\right)$.

Before corrosion experiments, an area of $4 \mathrm{~mm}^{2}$ was delimitated by microscratch. About 100 $\mathrm{Al}_{2} \mathrm{CuMg}$ particles and $50 \mathrm{Al}(\mathrm{Cu}, \mathrm{Mn}, \mathrm{Fe}, \mathrm{Si})$ particles were located, by optical microscopy for $\mathrm{AFM} / \mathrm{KFM}$ measurements.

Figure 1 shows scanning electron microscopy (SEM) image and the topographical image together with the potential map obtained simultaneous on the same area.

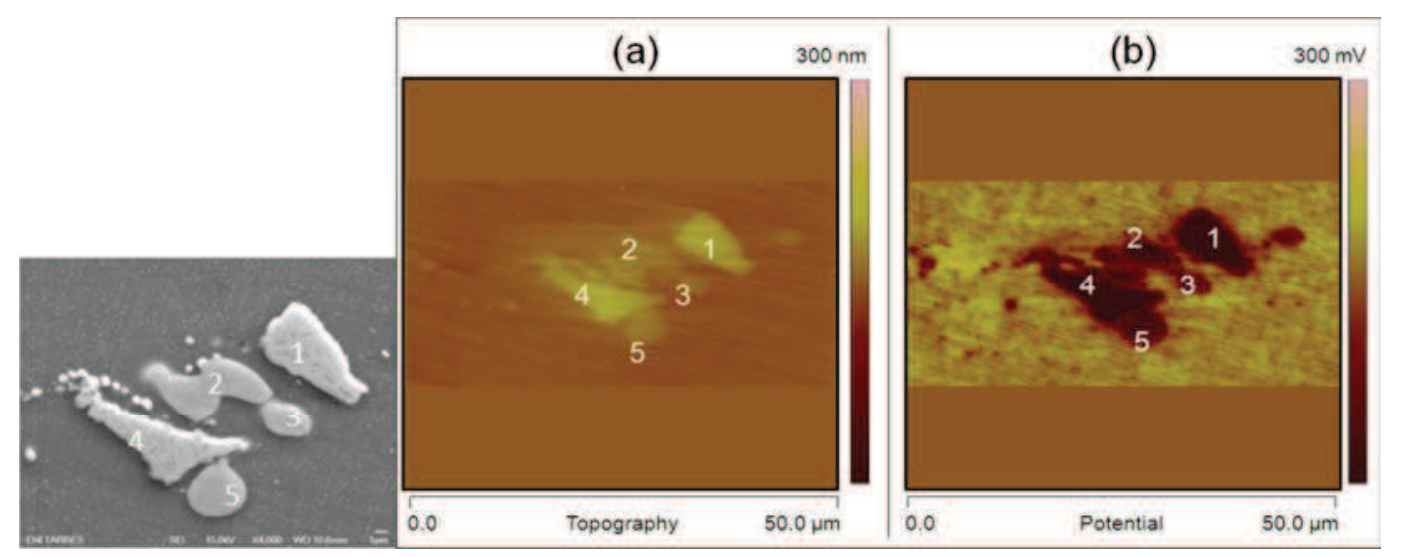

Figure 1: Observations of the over-ageing AA2024: SEM images; (a) topographic image and (b)

KFM potential map.

Energy-dispersive spectrometry (EDS) analysis allowed two types of intermetallic particles to be identified: the particles 1 and 4 correspond to $\mathrm{Al}(\mathrm{Cu}, \mathrm{Mn}, \mathrm{Fe}, \mathrm{Si})$ particles and the particles 2,3,5 correspond to $\mathrm{Al}_{2} \mathrm{CuMg}$ particles.

In some areas, the regions visible in the topography map are associated with intermetallic particles. These intermetallic particles can be observed protruding slightly from the surface, because of their higher hardness and therefore have a lower polishing rate in comparison to the $\mathrm{Al}$ matrix.

In the potential map, bright regions are associated with intermetallic particles; all intermetallic particles exhibit a Volta potential higher than the matrix. The $\mathrm{Al}(\mathrm{Cu}, \mathrm{Mn}, \mathrm{Fe}, \mathrm{Si})$ particles are brighter than the $\mathrm{Al}_{2} \mathrm{CuMg}$ particles on the potential map and thus have a higher potential.

It should be noted that the sense of the scale of the potential surface KFM image shown does not correspond to that of the scale of potential corrosion particles, it is reversed; a negative contrast corresponds to the nobler phase.

On the other hand, it should be noted that, the potential of coarse intermetallic particles was defined by the difference of the KFM potential between the intermetallic particles and the matrix remote from the particle.

Before corrosion experiments a statistical analysis of the KFM potential of coarse intermetallic particles as a function of the over-ageing temperature was made. For each over-ageing temperature, $20 \mathrm{AFM} / \mathrm{KFM}$ observations were performed. The KFM potential values for each type of coarse intermetallic particles were significantly scattered. We note a great dispersion of the KFM potential values; the values varies from -120 to $-430 \mathrm{mV}$ for $\mathrm{Al}_{2} \mathrm{CuMg}$ particles and from -190 to $-470 \mathrm{mV}$ for $\mathrm{Al}(\mathrm{Cu}, \mathrm{Mn}, \mathrm{Fe}, \mathrm{Si})$ particles. 
This dispersion of the KFM potential of the coarse intermetallic particles could be influenced by different parameters. In the literature are reminiscent of the environmental conditions of formation the oxide layer and differences in the thickness of the oxide layer [13,15], the means of preparation of the surface [16]. In order to limit the influence of the oxide film, the KFM observations were performed immediately after polishing.

This statistical analysis allows us to calculate a statistical value for the KFM potential for each type of coarse intermetallic particles as a function of the treatment temperature. Figure 2 presents the representative values for each particle type depending on the over-ageing temperature. For $\mathrm{Al}_{2} \mathrm{CuMg}$ particles, the KFM potential increases slightly with the over-ageing temperature, while for $\mathrm{Al}(\mathrm{Cu}, \mathrm{Mn}, \mathrm{Fe}, \mathrm{Si})$ particles, the KFM potential value decreases.

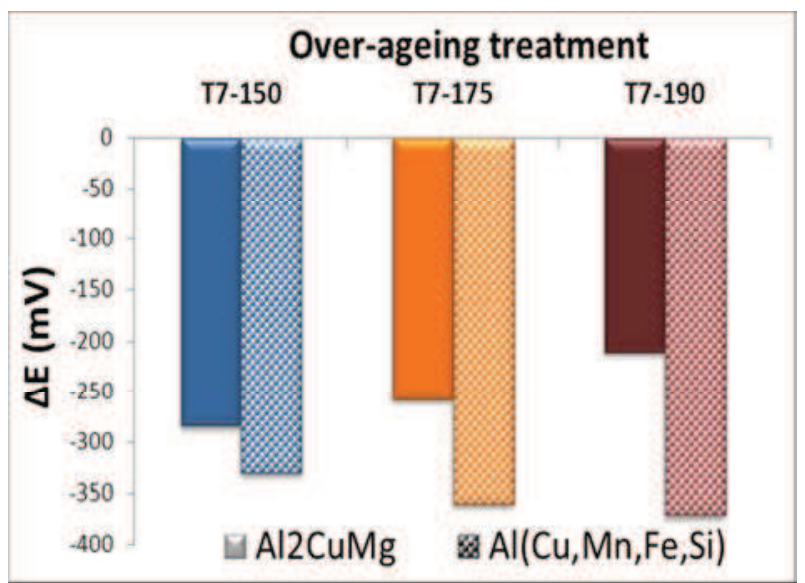

Figure 2: Representative values of the KFM potential of $\mathrm{Al}_{2} \mathrm{CuMg}$ particles and $\mathrm{Al}(\mathrm{Cu}, \mathrm{Mn}, \mathrm{Fe}, \mathrm{Si})$ particles relative to the matrix, as a function of the over-ageing temperature.

In Table 1 are presented the representative values with a standard deviation (SD). In literature are reported the KFM potential values for $\mathrm{Al}_{2} \mathrm{CuMg}$ particles on an AA2024-T351 alloy; these values are measured for one or few particles: $+280 \mathrm{mV}$ [15], +200 mV [15], +180 mV [17].

Statistical study of the KFM potential of $\mathrm{Al}_{2} \mathrm{CuMg}$ particles for 300 particles, on AA2024-T351 alloy indicates a mean value $-90 \mathrm{mV} \pm 45 \mathrm{mV}$ [18]. The $\mathrm{KFM}$ potential values for $\mathrm{Al}(\mathrm{Cu}, \mathrm{Mn}, \mathrm{Fe}, \mathrm{Si})$ particles was found between -200 to $-300 \mathrm{mV}$ [17].

Table 1: Values of the KFM potential for intermetallic particles.

\begin{tabular}{|c|c|c|}
\hline Metallurgical state & $\begin{array}{c}\mathrm{E}_{\mathrm{KFM}}(\mathrm{mV}) \\
\mathrm{Al}_{2} \mathrm{CuMg} \text { particles }\end{array}$ & $\begin{array}{c}\mathrm{E}_{\mathrm{KFM}}(\mathrm{mV}) \\
\mathrm{Al}(\mathrm{Cu}, \mathrm{Mn}, \mathrm{Fe}, \mathrm{Si}) \text { particles }\end{array}$ \\
\hline T7-150 & $-284 \pm 16$ & $-331 \pm 34$ \\
$\mathrm{~T} 7-175$ & $-258 \pm 13$ & $-360 \pm 43$ \\
$\mathrm{~T} 7-190$ & $-210 \pm 15$ & $-371 \pm 39$ \\
\hline
\end{tabular}

The average values of the chemical composition determined by EDS analysis before immersion are presented in Table 2 for $\mathrm{Al}_{2} \mathrm{CuMg}$ particles and Table 3 for $\mathrm{Al}(\mathrm{Cu}, \mathrm{Mn}, \mathrm{Fe}, \mathrm{Si})$ particles. The chemical composition was calculated for the same particles, analyzed by AFM/KFM and for which was calculated a representative value of the KFM potential. Calculated chemical composition of the $\mathrm{Al}_{2} \mathrm{CuMg}$ particles, is almost identical with the stoichiometric composition (Al-50\%at, $\mathrm{Cu}-25 \%$ at, $\mathrm{Mg}-25 \% \mathrm{at})$. 
Table 2: Chemical composition of $\mathrm{Al}_{2} \mathrm{CuMg}$ particles.

\begin{tabular}{|c|c|c|c|}
\hline $\begin{array}{c}\text { Metallurgical } \\
\text { state }\end{array}$ & Al (at.\%) & Cu (at.\%) & Mg (at.\%) \\
\hline T7-150 & $52.8 \pm 1.9$ & $24.6 \pm 0.8$ & $22.5 \pm 1.1$ \\
T7-175 & $51.3 \pm 0.9$ & $26.1 \pm 0.5$ & $23.5 \pm 0.5$ \\
T7-190 & $53.8 \pm 4.0$ & $24.5 \pm 2.4$ & $21.7 \pm 2.2$ \\
\hline
\end{tabular}

Table 3: Chemical composition of $\mathrm{Al}(\mathrm{Cu}, \mathrm{Mn}, \mathrm{Fe}, \mathrm{Si})$ particles.

\begin{tabular}{|c|c|c|c|c|c|c|}
\hline $\begin{array}{c}\text { Metallurgical } \\
\text { state }\end{array}$ & Al (at.\%) & Cu (at.\%) & Mn (at.\%) & Fe (at.\%) & Si (at.\%) & Mg (at.\%) \\
\hline T7-150 & $71.5 \pm 0.6$ & $16.3 \pm 1.5$ & $4.2 \pm 0.5$ & $6.1 \pm 0.6$ & $1.2 \pm 0.7$ & $0.8 \pm 0.1$ \\
T7-175 & $71.0 \pm 0.6$ & $17.6 \pm 0.8$ & $4.1 \pm 0.7$ & $5.8 \pm 0.5$ & $0.5 \pm 0.4$ & $0.8 \pm 0.1$ \\
T7-190 & $73.8 \pm 2.6$ & $15.4 \pm 1.4$ & $3.9 \pm 0.7$ & $5.1 \pm 0.8$ & $0.6 \pm 0.4$ & $1.1 \pm 0.2$ \\
\hline
\end{tabular}

Immersion test in $0.1 \mathrm{M} \mathrm{Na}_{2} \mathrm{SO}_{4}$ solution with $10^{-3} \mathrm{M} \mathrm{NaCl}$. After immersion test in chloride-containing sulfate solutions, the KFM potential respect to the matrix was measured, following to a statistical analysis obtain a representative value of the KFM potential of coarse intermetallic particles.

The samples were then immersed in $0.1 \mathrm{M} \mathrm{Na}_{2} \mathrm{SO}_{4}$ solution with $10^{-3} \mathrm{M} \mathrm{NaCl}$ for varying periods of time an examined again by AFM/KFM. After $30 \mathrm{~min}$ of immersion, the AFM/KFM observations reveal a slight decrease of the KFM potential for several $\mathrm{Al}_{2} \mathrm{CuMg}$ particles, but the topographical map indicates that no corrosion has occurred. After polishing, the samples were returned to the 0.1 $\mathrm{M} \mathrm{Na}_{2} \mathrm{SO}_{4}$ solution with $10^{-3} \mathrm{M} \mathrm{NaCl}$ for $60 \mathrm{~min}$. Figure 3 shows SEM and AFM/KFM observations of the over-aged 2024 (T7-150) aluminum alloy, after $60 \mathrm{~min}$ of immersion

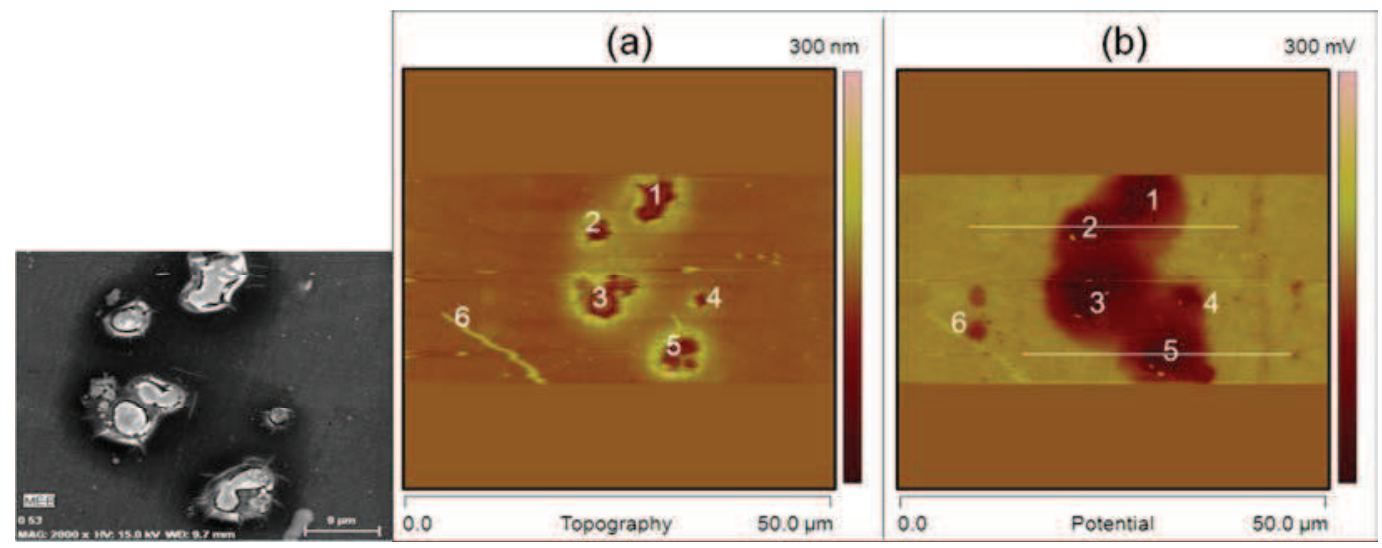

Figure 3: Observations of the over-aged AA2024 corroded 60 min: SEM observation; AFM map (a) and KFM map (b).

The $\mathrm{Al}_{2} \mathrm{CuMg}$ particles are partially corroded and dissolution of the matrix around the periphery of the particles is observed. The potential map shows that the contrast between the intermetallic particles and the matrix is more pronounced after corrosion test; for example, the $\mathrm{Al}_{2} \mathrm{CuMg}$ particles 1 and 2 present KFM potential of about $-485 \mathrm{mV}$ and $-520 \mathrm{mV}$ respectively.

The KFM potential values are more scattered and decrease down to value varying from -220 to -800 $\mathrm{mV}$, for the $\mathrm{Al}_{2} \mathrm{CuMg}$ particles and -220 to $-470 \mathrm{mV}$ for $\mathrm{Al}(\mathrm{Cu}, \mathrm{Mn}, \mathrm{Fe}, \mathrm{Si})$ particles. Figure 4 presents the KFM potential for each type of particles depending on the over-ageing temperature. The dispersion of the potential values is influenced by the different reactivity of the $\mathrm{Al}_{2} \mathrm{CuMg}$ particles, noting that some particles are strongly corroded, while others are not corroded. In the case of $\mathrm{Al}(\mathrm{Cu}, \mathrm{Mn}, \mathrm{Fe}, \mathrm{Si})$ particles they are less affected by the corrosive phenomena. 


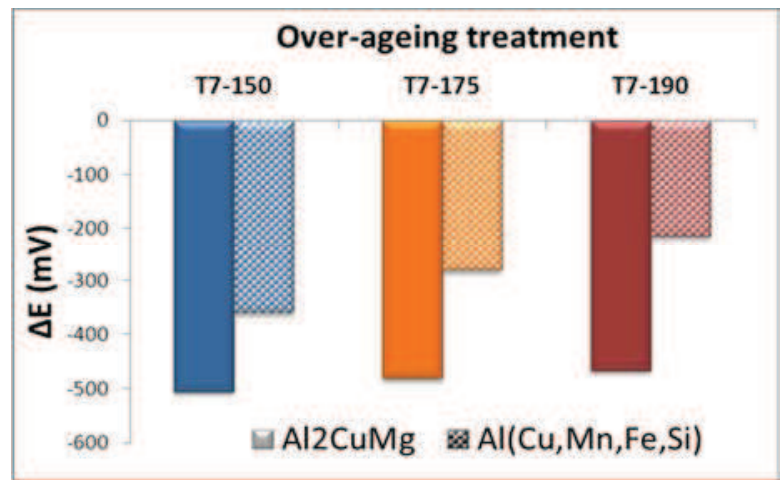

Figure 4: Representative values of the KFM potential of $\mathrm{Al}_{2} \mathrm{CuMg}$ particles and $\mathrm{Al}(\mathrm{Cu}, \mathrm{Mn}, \mathrm{Fe}, \mathrm{Si})$ particles relative to the matrix, as a function of the over-ageing temperature.

After corrosion experiments, EDS analyses were performed on all particles for which AFM/KFM measurements had been carried out. The results suggest changes in the chemical composition of particles and especially in the case of $\mathrm{Al}_{2} \mathrm{CuMg}$ particles. Thus, aluminum and magnesium content decreases and the copper content increases. On the other hand, the results show the presence of oxygen. We can note that changing in chemical composition of the $\mathrm{Al}_{2} \mathrm{CuMg}$ particle corresponds to a decrease of the KFM potential.

In Figure 5 and 6 are presented the chemical composition of the $\mathrm{Al}_{2} \mathrm{CuMg}$ particles and $\mathrm{Al}(\mathrm{Cu}, \mathrm{Mn}, \mathrm{Fe}, \mathrm{Si})$ particles before and after $60 \mathrm{~min}$ of immersion. A major change of chemical composition after corrosion is noted for particles type $\mathrm{Al}_{2} \mathrm{CuMg}$, the aluminum and magnesium content decrease down to 20 at.\% and 5 at.\% respectively, while the copper content reaches 39 at. $\%$. The oxygen content is also important, reaching $39 \%$ at.
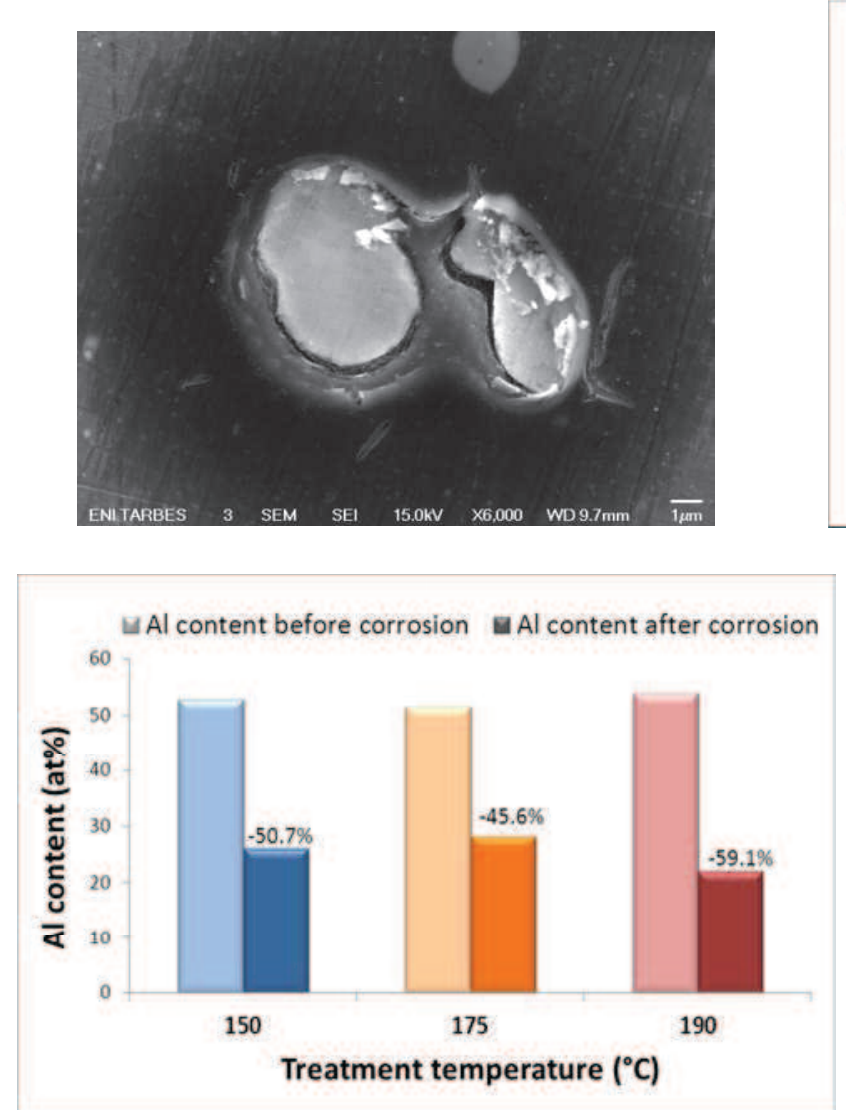
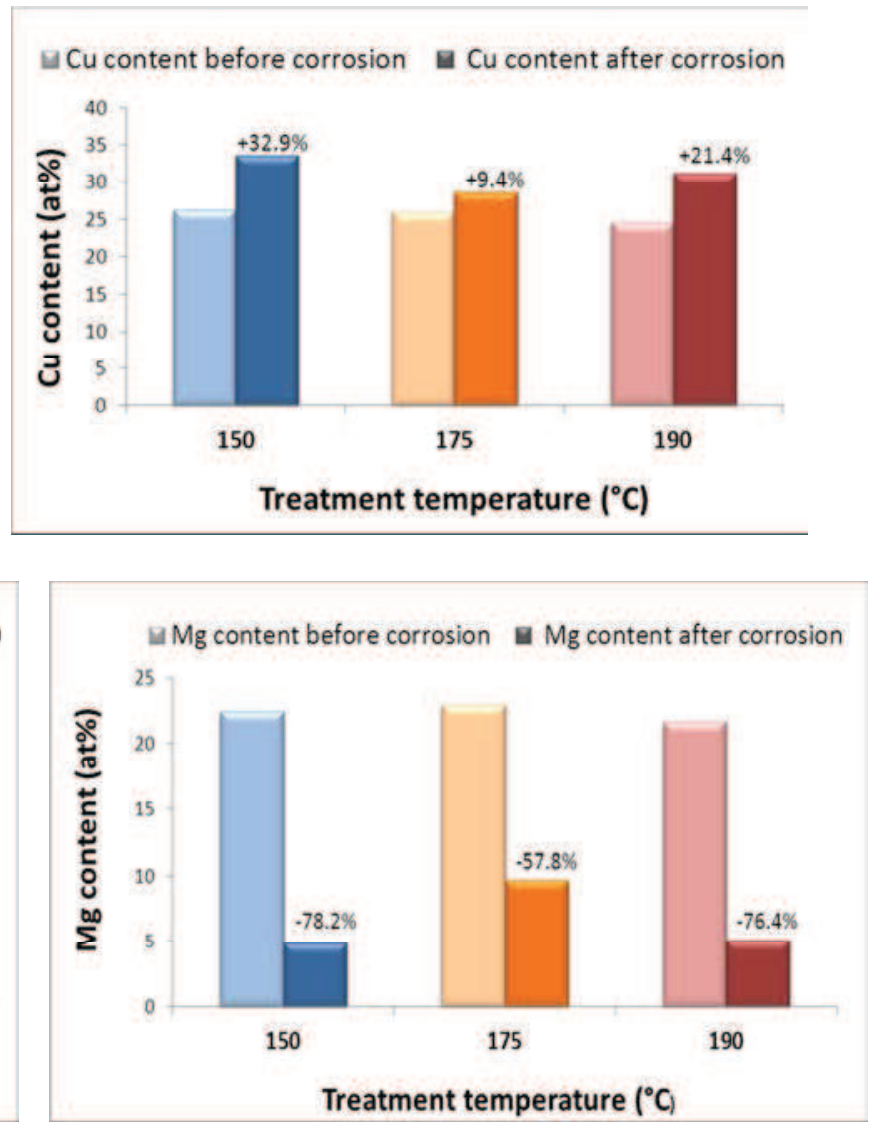

Figure 5: Evolution of chemical composition of $\mathrm{Al}_{2} \mathrm{CuMg}$ particles after immersion test. 
The chemical composition of $\mathrm{Al}(\mathrm{Cu}, \mathrm{Mn}, \mathrm{Fe}, \mathrm{Si})$ particles do not show significant changes, which makes us suppose that they are more resistant to corrosion. Moreover, the KFM potential value does not vary a lot after 60 min corrosion.
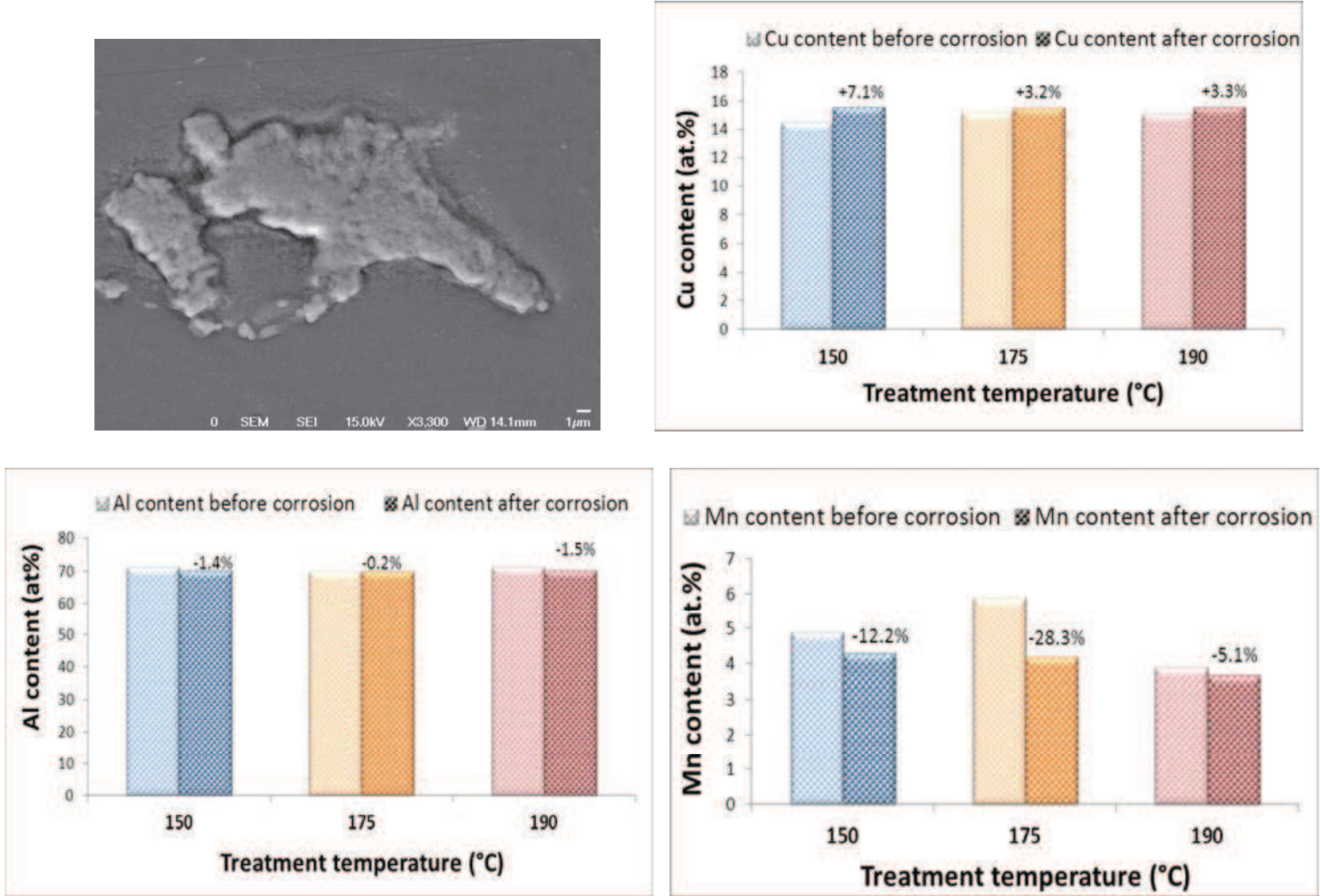

Figure 6: Evolution of chemical composition of $\mathrm{Al}(\mathrm{Cu}, \mathrm{Mn}, \mathrm{Fe}, \mathrm{Si})$ particles after immersion test.

Figure 7 represents an EDS map for the $\mathrm{Al}_{2} \mathrm{CuMg}$ particles. These maps indicated $\mathrm{Cu}$ enrichment at $\mathrm{Al}_{2} \mathrm{CuMg}$ particles and depletion of $\mathrm{Al}$ and $\mathrm{Mg}$ from these particles. Also, oxygen is present on the surface of the particles.
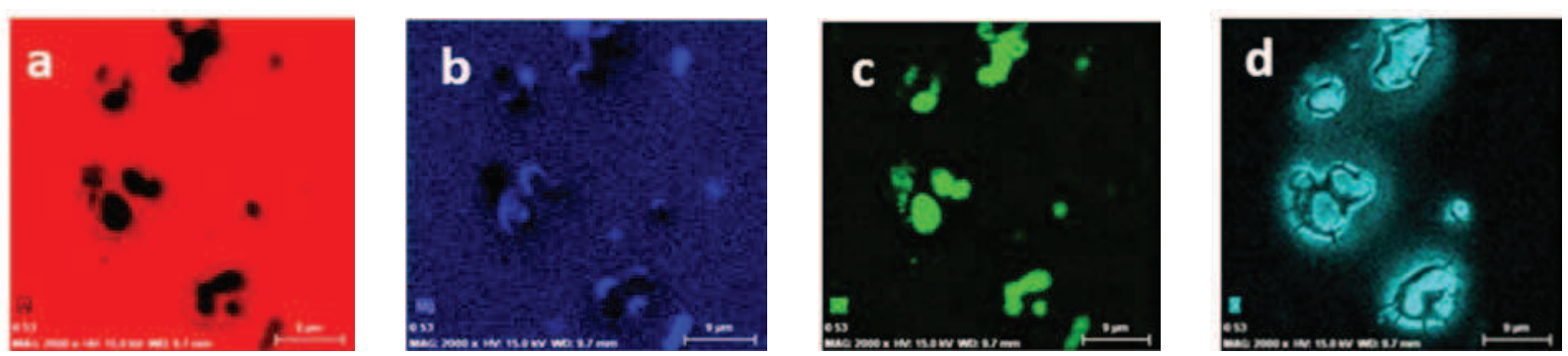

Figure7: X-ray maps from a region corresponding with that shown in fig. 6 indicating $\mathrm{Al}$ and $\mathrm{Mg}$ depletion from $\mathrm{Al}_{2} \mathrm{CuMg}$ particles $(\mathrm{a}, \mathrm{b})$; $\mathrm{Cu}$ enrichment at $\mathrm{Al}_{2} \mathrm{CuMg}$ particles (c); presence of oxygen $(d)$

A correlation between the KFM potential values and the corrosion behavior of coarse intermetallic particles was made. The corrosion behavior was characterized by the corrosion rate, noted by $\tau$. This parameter was defined as $\boldsymbol{\tau}=$ Number of particle corroded / Total number of particle.

The corrosion rate in the over-ageing state (T7) was compared with the corrosion rate in the peakaged state (T6). The results show that the corrosion rate is greatly diminished $(\approx 10 \%)$ for T7-175 and T7-190 states in comparison with T6-175 and T6 -190 states $(\approx 60 \%)$. On the contrary, the corrosion rate for T7- 150 state $(55 \%)$ is almost similar with the corrosion rate for T6-150 state $(53 \%)$. 
Tabel 4: Corrosion rate for 2024 aluminum alloy in T6 and T7 states.

\begin{tabular}{|c|c|c|c|c|c|c|}
\hline $\begin{array}{c}\text { Metallurgical } \\
\text { state }\end{array}$ & T6-150 & T7-150 & T6-175 & T6-175 & T6-190 & T7-190 \\
\hline $\begin{array}{c}\text { Corrosion } \\
\text { rate }\end{array}$ & $55 \%$ & $53 \%$ & $45 \%$ & $7.5 \%$ & $63 \%$ & $10 \%$ \\
\hline
\end{tabular}

\section{Conclusions}

The AFM/KFM potential values are very scattered hence statistical analyses before end after corrosion tests were made.

Before immersion test, the $\mathrm{AFM} / \mathrm{KFM}$ potential values of the $\mathrm{Al}_{2} \mathrm{CuMg}$ particles is close to -284 $\mathrm{mV}$ and $-371 \mathrm{mV}$ for the $\mathrm{Al}(\mathrm{Cu}, \mathrm{Mn}, \mathrm{Fe}, \mathrm{Si})$ particles. The over-ageing temperature has a low influence on the AFM/KFM potential values.

After immersion test, the $\mathrm{Al}_{2} \mathrm{CuMg}$ particles are affected by the corrosion phenomena, while the $\mathrm{Al}(\mathrm{Cu}, \mathrm{Mn}, \mathrm{Fe}, \mathrm{Si})$ particles are less affected. The $\mathrm{AFM} / \mathrm{KFM}$ potential values is close to $-504 \mathrm{mV}$ for $\mathrm{Al}_{2} \mathrm{CuMg}$ and $-359 \mathrm{mV}$ for $\mathrm{Al}(\mathrm{Cu}, \mathrm{Mn}, \mathrm{Fe}, \mathrm{Si})$ particles.

The corrosion rate was also characterized. A decrease of the corrosion rate for the over-ageing state is observed.

\section{Acknowledgement}

This article was produced under the project "Supporting young PhD Student with frequency by providing doctoral fellowships" - ID 52826 co-financed from the European Social Fund, through the Sectorial Operational Program Development of Human Resources.

\section{References}

[1] S. Wernich, R. Pinner (eds.), Finnishing Publication No. 5, Teddington, UK (1986)

[2] J. Galvele and S. De Micheli, Corros. Sci. 10 (1970),p.795

[3] R. Buchheit, R. Grant, P. Hlava, B. McKenzie and G. Zender, J. Electrochem. Soc. 144 (1997), p.2621

[4] C. Blanc, B. Lavelle and G. Mankowski,.Corros. Sci. 39 (1997), p.495

[5] V. Guillaumin and G. Mankowski, Corros. Sci. 41 (1999), p.421

[6] Z. Szklarska-Smialowska, Corros. Sci. 28 (1972), p.388

[7] W. Zhang and G.S. Frankel, J. Electrochem. Soc. 149 (2002),p.1510

[8] X. Liu, G.S. Frankel, B. Zoofan and S.I. Roklin, Corros. Sci. 46 (2006), p.405

[9] L. Lacroix, L. Ressier, C. Blanc and G. Mankowski, J. Electrochem. Soc. 155 (2008), p.131

[10] C. Augustin, E. Andrieu, C. Baret-Blanc, J. Delfosse and G. Odemer, J. Electrochem. Soc. 157 (2010),p.428

[11] P. Schmutz and G.S. Frankel, J. Electrochem. Soc. 145 (1998), p.2285

[12] P. Schmutz and G.S. Frankel, J. Electrochem. Soc. 145 (1998), p.2295

[13] V. Guillaumin, P. Schmutz and G.S. Frankel, J. Electrochem. Soc. 148 (2001), p.163

[14] N. Radutoiu, L.Lacroix, J. Alexis, M. Abrudeanu, J-A Petit, Trans Tech Periodicals, Switzerland (2012), In press

[15] P. Leblanc and G.S. Frankel, J. Electrochem. Soc. 149 (2002), p.239

[16] T.H. Muster and A. E. Hughes, J. Electrochem. Soc. 153 (2006), p.474

[17] P. Campestrini, E.P.M van Westing, H.W. van Rooijen and J.H.W. de Wit, Corros. Sci. 42 (2000), p. 1853

[18] L. Lacroix, L. Ressier, C. Blanc and G. Mankowski, J. Electrochem. Soc. 155 (2008), p.8 